\title{
Effect of Temperature on Biology of Oligonychus mangiferus (Rahman and Sapra) (Acari: Tetranychidae) \\ Abu-shosha, M. A. ${ }^{1}$; A. A. Abdallah ${ }^{2}$; N. M. Abdel-Aziz ${ }^{1}$ and A. S. Mahmoud ${ }^{1}$ \\ ${ }^{1}$ Agric. Zoology and Nematology Dept., Faculty of Agriculture, Al-Azhar University branch Assiut. \\ ${ }^{2}$ Agric. Zoology and Nematology Dept., Faculty of Agriculture, Al-Azhar University.
}

\section{ABSTRACT}

Life history and reproductive parameters of the mango red spider mite, Oligonychus mangiferus (Rahman and Sapra) (Acari: Tetranychidae) were studied to investigate its response to different temperatures $\left(25,28\right.$ and $\left.31^{\circ} \mathrm{C}\right)$, with $70 \pm 5 \%$ R.H. on Mangifera indica L. Baladi variety in the laboratory. The results showed that the developmental time of the individuals shortened with increasing temperature. The total immature stages was the longest period (7.51 day for the female and 7.46 day for the male) at $25^{\circ} \mathrm{C}$, while at $31^{\circ} \mathrm{C}$ was the shortest period (6.48 and 6.46 day, respectively). The life cycle was the longest period (12.18 day for the female and 11.71 day for the male) at $25^{\circ} \mathrm{C}$, while at $31^{\circ} \mathrm{C}$ was the shortest period (10.78 and 10.38 day, respectively). So, the mean generation time was the longest $\left(20.12\right.$ days) at $25^{\circ} \mathrm{C}$, followed by $28{ }^{\circ} \mathrm{C}\left(19.06\right.$ days) and then at $31^{\circ} \mathrm{C}$ was the shortest $(17.87$ days). On the contrary, total fecundity was 32.50 eggs $(2.05 \mathrm{eggs} / \mathrm{P} /$ day $)$ at $25^{\circ} \mathrm{C}$, then at $28^{\circ} \mathrm{C}$ it reached $30.17 \mathrm{eggs}(2.01 \mathrm{eggs} / \mathrm{P} / \mathrm{day})$ and 26.83 eggs $(1.93 \mathrm{eggs} / \mathrm{q} / \mathrm{day})$ at $31^{\circ} \mathrm{C}$, respectively. The mean generation time recorded the shortest $(17.87$ days $)$ at $31^{\circ} \mathrm{C}$, while the fecundity recorded the highest rate at $25^{\circ} \mathrm{C}(32.50 \mathrm{eggs} ; 2.05 \mathrm{eggs} / \mathrm{Q} /$ day $)$. Based on these results, we can predict the presence of $O$. mangiferus on mango. Therefore, it should be easily to determine the best time to control this pest.

Keywords: Life history, life cycle, spider mite, Oligonychus mangiferus, generation time, and fecundity.

\section{INTRODUCTION}

The mango red spider mite, Oligonychus mangiferus (Rahman and Sapra), is a serious mango pest, that is widely distributed in many countries, including Egypt, China, Hawaii, India, Israel, Mozambique, Myanmar, Pakistan, Peru, Singapore, Taiwan, and Thailand (Jeppson et al. 1975; Waterhouse 1993; Wate 2002). In Egypt, O. mangiferus is a pest of cotton and considered as the second serious pest on pomegranate (Moutia 1958; Mohamed 1963). In recent years, its population increased rapidly on mango trees, especially the nurseries. It is a pest attacking peach, pear, litchi, loquat, grape and sweetsop (Migeon and Dorkeld 2017). Oligonychus mangiferus can also infest different varieties of mango feeding on the upper leaf surface, destroying leaf cells, and forming pale patches on leaves. The mite population rapidly increases to a high density especially in dry seasons. Feeding causes the mango leaves to turn pale, greatly influencing the photosynthesis of the mango tree producing a drying effect and premature leaf drop and indirectly reducing the quality and quantity of mango fruits, (Al-Azzazy 2005; Ming-Ying Lin 2013).

\section{MATERIALS AND METHODS}

\section{A - Source of phytophagous mite:}

Oligonychus mangiferus was collected from leaves of mango trees at the farm of faculty of Agriculture, Al - Azhar University, Assuit branch as mobile individuals.

B - Rearing of Oligonychus mangiferus mite:

Mite culture: stock culture of mites was established by placing a copulated female together on mango leaf (Mangifera indica) situated upside down on cotton wool soaked in water in $9 \mathrm{~cm}$ diameter Petri-dish and left to deposit eggs. The edges of the leaf were lined with a wet cotton barrier until we get high numbers of $O$. mangiferus.

The float leaf method was used to rear $O$. mangiferus during the life history study. Circularly mango leaf disc (2.5 $\mathrm{cm}$ in diameter) was cut from El-Baladi mango leave and a disc was placed with the upper surface face-up in a Petri dish (10 cm diameter) situated on cotton wool soaked in water. Float leaf discs were replaced every 4 days.

\section{C- Life history observations}

Forty mites females from the stock population were introduced into a float leaf and allowed to lay eggs. The adults were then removed from the float leaf, leaving only one egg on the foliar disc. Examining for eggs were every 12 $\mathrm{h}$, until larvae hatched. The sex of the mite can be distinguished in the late deutonymphal stage. Each Deutonymph stage of female was provided with numbers of adult males from the stock colony for mating. Checking of Petri dishes were for the producing of eggs every day after the deutonymph females transformed to adult stage, and the eggs were removed. Each male deutonymph was provided with an adult female from the stock colony to observe the adult male longevity. All experiments were kept at 25, 28, and $31 \mathrm{OC}$ and $70 \pm 5 \%$ R.H. The developmental time of each stage, longevity, preoviposition, oviposition periods and fecundity of females were computed from the observed data.

\section{Statistical analysis of data:}

F. test and L.S.D. values used for comparison between means of the treatments of the biology of $O$. mangiferus with different temperatures.

\section{Life table parameters}

O. mangiferus life tables were calculated with the aid of a computer program of Abou-Setta et al., (1986). The doubling time of a population $(\mathrm{DT})=$ by equation Dent and Walton (1997)

The doubling time of a population $(D T)=\frac{\log 2}{r m}$

\section{RESULTS AND DISCUSSION}

\section{Biology of Oligonychus mangiferus :}

The mango red mite, Oligonychus mangiferus was reared at 25,28 and $31^{\circ} \mathrm{C}$ and $70 \pm 5 \%$ R.H. on mango leaves Baladi variety, which are presented in the following:-

I-Developmental period (life cycle):-

Data presented in table (1) showed that the average female's incubation period of $\mathrm{O}$. mangiferus was decreased when temperature increased, as it was $4.67,4.44$ and 4.31 days at 25,28 and $31^{\circ} \mathrm{C}$, respectively, The differences were significant between 25 and $31^{\circ} \mathrm{C}$. For male, it averaged $4.25,4.17$ and 3.92 days at the same temperature degrees, respectively, The differences were not significant between 25 and $28^{\circ} \mathrm{C}$, while it was significant between at 31 with 25 or $28^{\circ} \mathrm{C}$. 
Table 1. Duration (days \pm S.D) of Oligonychus mangiferus reared on mango (Baladi variety) at constant temperatures and relative humidity $70 \pm 5 \%$

\begin{tabular}{|c|c|c|c|c|c|c|}
\hline Stages & Sex - & \multicolumn{3}{|c|}{ Temperatures $\left({ }^{\circ} \mathrm{C}\right)$} & \multicolumn{2}{|c|}{ LSD 5\% LSD 1\% } \\
\hline & O & $4.67 \pm 0.34 \mathrm{~B}$ & $4.44 \pm 0.42 \mathrm{AB}$ & $4.30 \pm 0.30 \mathrm{~A}$ & 0.24 & 0.32 \\
\hline Incubation Period & 育 & $4.25 \pm 0.26 \mathrm{~B}$ & $4.17 \pm 0.25 \mathrm{~B}$ & $3.92 \pm 0.29 \mathrm{~A}$ & 0.22 & 0.30 \\
\hline & o & $2.53 \pm 0.27$ & $2.39 \pm 0.40$ & $2.17 \pm 0.24$ & - & - \\
\hline Larva & 言 & $2.54 \pm 0.26$ & $2.29 \pm 0.33$ & $2.17 \pm 0.25$ & - & - \\
\hline Proto numnh & o & $2.42 \pm 0.26$ & $2.31 \pm 0.35$ & $2.14 \pm 0.23$ & - & - \\
\hline Гтото- пупрп & 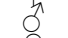 & $2.42 \pm 0.51$ & $2.21 \pm 0.26$ & $2.08 \pm 0.19$ & - & - \\
\hline Deuto- nymph & 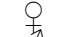 & $2.56 \pm 0.29$ & $2.33 \pm 0.20$ & $2.17 \pm 0.24$ & - & - \\
\hline & 8 & $2.50 \pm 0.30$ & $\begin{array}{c}2.33 \pm 0.33 \\
703\end{array}$ & $2.21 \pm 0.26$ & - & \\
\hline Total Immatures & 去 & $\begin{array}{l}7.51 \pm 0.38 \mathrm{C} \\
7.46 \pm 0.58 \mathrm{C}\end{array}$ & $\begin{array}{l}7.03 \pm 0.40 \mathrm{~B} \\
6.83 \pm 0.39 \mathrm{~B}\end{array}$ & $\begin{array}{l}6.48 \pm 0.32 \mathrm{~A} \\
6.46 \pm 0.26 \mathrm{~A}\end{array}$ & $\begin{array}{l}0.24 \\
036\end{array}$ & $\begin{array}{l}0.32 \\
0.48\end{array}$ \\
\hline $1: f_{-1}$ & 0 & $12.18 \pm 0.48 \mathrm{C}$ & $11.47 \pm 0.44 \mathrm{~B}$ & $10.78 \pm 0.46 \mathrm{~A}$ & 0.29 & 0.39 \\
\hline life cycle & है & $11.71 \pm 0.62 \mathrm{C}$ & $11.00 \pm 0.37 \mathrm{~B}$ & $10.38 \pm 0.31 \mathrm{~A}$ & 0.38 & 0.51 \\
\hline
\end{tabular}

The duration of the developmental stages of $O$. mangiferus immature stages increased when the temperature decreased. Data in table (1) illustrated that the duration of female larval stages averaged 2.53, 2.39 and 2.17 days; protonymph averaged $2.42,2.31$ and 2.14 days and deutonymph averaged $2.56,2.33$ and 2.17 days at 25 , 28 and $31^{\circ} \mathrm{C}$, respectively.

The female developmental time (life cycle) of $O$. mangiferus averaged $12.18,11.47$ and 10.78 days at temperatures of 25,28 and $31^{\circ} \mathrm{C}$, respectively. The differences were significant between 25 and $31^{\circ} \mathrm{C}$. Male followed similar trend of female, but having often shorter periods. The male larval stage average $2.54,2.29$ and 2.17 days; protonymph average $2.42,2.21$ and 2.08 days while, deutonymph lasted 2.50, 2.33 and 2.21 days at 25, 28 and $31^{\circ} \mathrm{C}$, respectively, the differences were significant between the three temperatures studied.

This study indicated that the development of $O$. mangiferus increased as increasing temperature. $\mathrm{Fu}$ and Zhang (2002), Abou- Awad et al. (2011) and Ming-Ying Lin (2013) also studied the biological parameters of $O$. mangiferus at various temperatures, and showed a similar tendency, although, Fu and Zhang (2002) reported a shorter developmental time, while Abou-Awad et al. (2011) obtained a longer development at $15^{\circ} \mathrm{C}$ but it was shorter at 23 and $31{ }^{\circ} \mathrm{C}$. Difference in relative humidities from 65 to $75 \%$ may explain the differences in development time(Abou-Awad et al., 2011).

The developmental time of each stage of $O$. mangiferus is generally shorter for males than females (Abou-Awad et al. 2011; Ming-Ying Lin 2013; Rai et al. 1988). The same results are true for O. perseae (Aponte and McMurtry 1997) and O. coffeae (Gotoh and Nagata 2001). In the present study such a difference between the sexes was not clear. The developmental time of males was shorter than that of females, and males have a shorter incubation period under all tested postembryonic immature stages, consequently their entire immature development period was shorter than that of females, but this difference was not statistically significant.

\section{II: Reproduction and life table parameters:-}

The used temperatures obviously affected adult female longevity (Table 2), Maximum female longevity was obtained at $25^{\circ} \mathrm{C}$, while the minimum period was recorded at $31^{\circ} \mathrm{C}$. Female longevity averaged $22.78,20.85$ and 18.86 days at 25,28 and $31^{\circ} \mathrm{C}$, respectively. The preoviposition period was $0.86,0.69$ and 0.53 days; while the oviposition period averaged 15.89, 14.83 and 13.89 days; and the post-oviposition period averaged $6.03,5.33$ and 4.44 at 25,28 and $31^{\circ} \mathrm{C}$, respectively. High significant differences were found in the oviposition and postoviposition phases between the three tested temperatures, while no significant differences were found in preoviposition duration between 28 and $31{ }^{\circ} \mathrm{C}$ but it was significant differences for $25^{\circ} \mathrm{C}$.

The total and daily rate female fecundity averaged $32.50,2.05 \& 30.17,2.03$ and 26.83, 1.93 eggs/day at 25, 28 and $31^{\circ} \mathrm{C}$, respectively. The life span for female averaged $34.96,32.32$ and 29.64 at 25,28 and $31^{\circ} \mathrm{C}$, respectively, while it averaged $32.46,31.00$ and 29.05 at 25,28 and $31^{\circ} \mathrm{C}$ for male, respectively. The differences were statistically significant between the three temperatures studied, (Table 2).

Longevity period of spider mite decreases as increasing of temperature (Zaher and Shehata 1971; Fu and Zhang 2002; Abou-Awad et al. 2011; Ming-Ying Lin 2013). The longevity of $O$. mangiferus recorded in this study resembles that of Zaher and Shehata (1971), Fu and Zhang (2002) and Ming-Ying Lin (2013) while Nangia et al. (1989) and Abou-Awad et al. (2011) found that $O$. mangiferus lived considerably longer.

Table 2. Duration (days \pm S.D) of Oligonychus mangiferus reared on mango (Baladi variety) at constant temperature and relative humidity $70 \% \pm 5 \%$

\begin{tabular}{|c|c|c|c|c|c|c|}
\hline \multirow{2}{*}{ Stages } & \multirow{2}{*}{ Sex } & \multicolumn{3}{|c|}{ Temperatures $\left({ }^{\circ} \mathrm{C}\right)$} & \multirow{2}{*}{$\begin{array}{l}\text { LSD } \\
5 \%\end{array}$} & \multirow{2}{*}{$\begin{array}{l}\text { LSD } \\
1 \%\end{array}$} \\
\hline & & $25^{\circ} \mathrm{C}$ & $28^{\circ} \mathrm{C}$ & $31^{\circ} \mathrm{C}$ & & \\
\hline Pre-oviposition & & $0.86 \pm 0.23 \mathrm{~B}$ & $0.69 \pm 0.25 \mathrm{~A}$ & $0.53 \pm 0.12 \mathrm{~A}$ & 0.14 & 0.19 \\
\hline Oviposition & o & $15.89 \pm 1.17 \mathrm{C}$ & $14.83 \pm 1.58 \mathrm{~B}$ & $13.89 \pm 1.18 \mathrm{~A}$ & 0.14 & 0.19 \\
\hline Post-oviposition & t & $6.03 \pm 1.12 \mathrm{C}$ & $5.33 \pm 0.45 \mathrm{~B}$ & $4.44 \pm 0.48 \mathrm{~A}$ & 0.50 & 0.67 \\
\hline Total average of eggs & to & $32.50 \pm 2.01 \mathrm{C}$ & $30.17 \pm 3.01 \mathrm{~B}$ & $26.83 \pm 4.55 \mathrm{~A}$ & 2.25 & 3.00 \\
\hline Daily rate & 호 & 2.05 & 2.03 & 1.93 & & \\
\hline I onoryity & o & $22.78 \pm 1.96 \mathrm{C}$ & $20.85 \pm 1.73 \mathrm{~B}$ & $18.86 \pm 1.01 \mathrm{~A}$ & 1.08 & 1.44 \\
\hline Longevity & 卒 & $21.75 \pm 1.29 \mathrm{C}$ & $20.00 \pm 1.28 \mathrm{~B}$ & $18.67 \pm 1.15 \mathrm{~A}$ & 1.03 & 1.39 \\
\hline & 0 & $34.96 \pm 1.80 \mathrm{C}$ & $32.32 \pm 1.64 \mathrm{~B}$ & $29.64 \pm 1.21 \mathrm{~A}$ & 1.05 & 1.40 \\
\hline Life span & 索 & $32.46 \pm 1.37 \mathrm{C}$ & $31.00 \pm 1.33 \mathrm{~B}$ & $29.05 \pm 1.20 \mathrm{~A}$ & 1.08 & 1.45 \\
\hline
\end{tabular}

Table (3) showed that the net reproductive rate $(R O)$ decreased when temperature increased. These values were $27.59,27.21$ and 23.88 eggs population/ female at 25,28 and $31{ }^{\circ} \mathrm{C}$, respectively. The intrinsic rate of increase $(\mathrm{rm})$ was increased as the temperatures increased where it reached $0.165,0.173$ and $0.178 \mathrm{eggs} / q /$ day; as well as the 
corresponding values of finite rate of increase (erm) were $1,179,1.189$ and 1.194 at 25,28 and $31{ }^{\circ} \mathrm{C}$, respectively. The mean generation time (T) was 20.12, 19.06 and 17.87 days, while the gross reproduction rate (GRR) was 32.39, 30.01 and 26.72 at 25,28 and $31{ }^{\circ} \mathrm{C}$, respectively. The percentage $50 \%$ mortality decreased when temperature increased where it averaged $33.50,32.00$ and 29.50 days at 25,28 and $31^{\circ} \mathrm{C}$, respectively. Mites needed to an average of $4.20,4.00$ and 3.89 at 25,28 and $31{ }^{\circ} \mathrm{C}$ to double their numbers, respectively.

The highest $r m$ values of $O$. mangiferus in the present study and that of Ming-Ying Lin (2013) Fu and Zhang (2002) and Abou-Awad et al. (2011) averaged $0.178,0.182,0.396$ and 0.125 , when the temperature was $31,29,28,31{ }^{\circ} \mathrm{C}$, respectively. On the other hand, Wrensch (1985) found that the highest $r m$ values of various Tetranychus species ranged from 0.355 to 0.46 . Saito (1979) reported that Panonychus species living on woody plants, would have a lower $\mathrm{rm}$ values than Tetranychus spp. Also, Sabelis (1985) accepted Saito's observations concerning other genera of tetranychid mites including Oligonychus. Nevertheless, $O$. perseae and $O$. coffeae are two species morphologically similar to $O$. mangiferus. The biological parameters of these species were carefully investigated by Aponte and McMurtry (1997) and Gotoh and Nagata (2001). Compared to this study, they observed a similar developmental period, slightly longer longevity, and a higher fecundity. However, the highest $\mathrm{rm}$ values of these two species were 0.215 and 0.144 , respectively, both at $30^{\circ} \mathrm{C}$. Thus, the higher $r m$ of
O. mangiferus observed by $\mathrm{Fu}$ and Zhang (2002) is probably uncommon. There are many factors could affect the performance of $O$. mangiferus and cause this variation. These factors include experimental conditions, method of handling during the study, food type, and importantly, mite strain, which will have adapted to the local climate and host plant varieties. this variation highlights the exigency of conducting a life history study on local strains to obtain population parameters suitable for the application to local agricultural systems.

Table 3. Effect of temperatures on the life table parameters of the red spider mite Oligonychus mangiferus reared on mango (Baladi)

\begin{tabular}{|c|c|}
\hline Population parameters & $\frac{\text { Temperature }\left(^{\circ} \mathrm{C}\right)}{25^{\circ} \mathrm{C} 28^{\circ} \mathrm{C} 31^{\circ} \mathrm{C}}$ \\
\hline$\overline{\mathrm{Net}}$ & 27.5927 .2123 .88 \\
\hline of increases $\left(\mathrm{r}_{\mathrm{m}}\right)$ & 0.1650 .1730 .178 \\
\hline of increase $\left(\mathrm{e}^{\mathrm{rm}}\right)$ & 1.179 \\
\hline e GT'(day) & 20.12 \\
\hline rate (GRR) & 32.3930 .0126 .72 \\
\hline & 33.5032 .0029 .50 \\
\hline The doubling time of a population & $\begin{array}{lll}4.20 & 4.00 & 3.89\end{array}$ \\
\hline
\end{tabular}

Figure (1) Explains in detail the capability of reproductive of $O$. mangiferus females on mango Baladi variety at different temperatures, age-specific survival rate (Lx), age-specific fecundity (Mx), and age-specific maternity $(\mathrm{LxMx})=$ Net reproductive rate $(R O)$. It is noted that egg-laying began early as the temperature increased, on day 13, 12 and 11 after eggs were laid, at 25, 28 and 31 ${ }^{\circ} \mathrm{C}$ respectively.

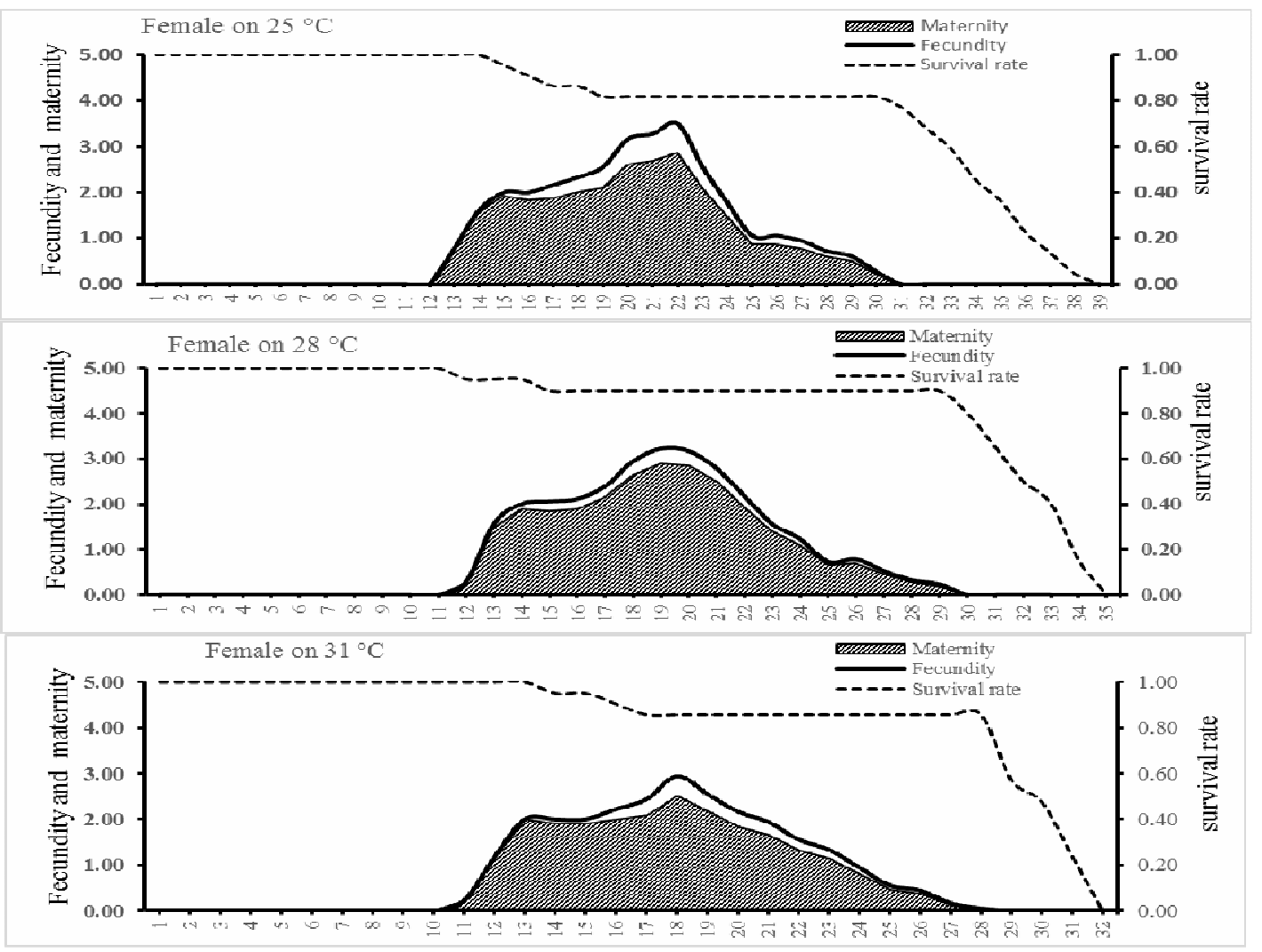

Fig. 1. Age-specific survival rate (Lx, choppy line), fecundity (Mx, bold line) and maternity (LxMx, Shaded area) of Oligonychus mangiferus

It was gradually delayed as the temperature decreased. Life time oviposition was skewed left, because females laid high number of eggs at the initial period and subsequently exhibited lower fecundity. Interestingly, the 
daily egg-laying rate was gradually increasing and its peak in day 22nd, 19th and 18th with 3.50, 3.22 and 2.94 eggs, at 25,28 and $31{ }^{\circ} \mathrm{C}$, respectively. After the founding eggs were laid, then began gradually decreasing with age increase until egg laying stopped. The results agree with these obtained by Ming-Ying Lin (2013).

\section{REFERENCES}

Abou-Awad, B.A., Al-Azzazy, M.M. and Afia, S.I. (2011): Effect of temperature and relative humidity on the rate of development, fecundity and life table parameters of the red spider mite Oligonychus mangiferus (Rahman and Sapra) (Acari: Tetranychidae). Archives of Phytopathology and Plant Protection Vol. 44, No. 19, 1862-1866.

Abou-Setta M.M., Dorrell R.W. \& Childres C.C. (1986): Life 48: a BASIC computer program to calculate life table parameters for an insect or mites species. - Fla. Entomol. 69: 690-697.

Al-Azzazy, M.M. (2005) : Integrated management of mites infesting mango trees [PhD Thesis]. Cairo (Egypt): Al-Azhar University.

Aponte, O. and McMurtry, J. A. (1997) : Damage on 'Hass' avocado leaves, webbing and nesting behaviour of Oligonychus perseae (Acari: Tetranychidae) Experimental \& Applied Acarology, 21, 265-272.

Dent, D.R. and Walton, M.P. (1997): Methods in ecological and Agricultural Entomology. Printed and bound in the UK at the University Press, Cambridge . 387 pp.

Fu, Y.G. and Zhang, F.Q. (2002): Effects of temperatures on development and reproduction of Oligonychus mangiferus (Acari: Tetranychidae). Chin. J. Trop Crop 23:47-52 (in Chinese).

Gotoh, T. and Nagata, T. (2001): Development and reproduction of Oligonychus coffeae (Acari: Tetranychidae) on tea. Int. J. Acarol., 27:293-298.

Jeppson, L. ; Keifer, H. and Baker, E. (1975) : Mites Injurious to Economic Plants. University of California Press, Berkeley, USA. 614 pp.

Lactin, D.J. ; Holliday, N.J. ; Johnson, D.L. and Craigen, R. (1995): Improved rate model of temperaturedependent development by arthropods. Environ Entomol 24:68-75.
Migeon, A. and Dorkeld, F. (2017): Spider Mites Web: a comprehensive database for the Tetranychidae. http://www1.montpellier.inra.fr/cbgp/spmweb/no te species.php?id=561\#hosts.

Ming-Ying, L. (2013):Temperature-dependent life history of Oligonychus mangiferus (Acari: Tetranychidae) on Mangifera indica. Exp. Appl. Acarol., 61:403-413.

Mohamed, I.I. (1963): Acarine mites occurring on cotton plants in Egypt. Bull Soc. Entomol Egypte. 46:511.

Moutia, L.A. (1958): Contribution to the study of some phytophagous acarina and their predators in Mauritius. Bull Entomol Res. 49:59-75.

Nangia, N.; Jagadish, P.S. and Nageshchandra, B.K. (1989): Biology and control of Oligonychus mangiferus (Rahman and Sapra) (Acari: Tetranychidae) on Terminalia spp., important host plants of silkworms. Mysore J. Agric. Sci. 23:355-358.

Rai, B. ; Shah, A. and Patel, R. (1988): Biology of Oligonychus mangiferus (Tetranychidae Acarina), a pest of mango in Gujarat. Gujarat Agric. Univ. Res. J., 14:5-10.

Sabelis, M..W. (1985): Reproductive strategies. In: Helle W, Sabelis MW (eds) World crop pest 1A: Spider mites: their biology, natural enemies and control. Elsevier, Amsterdam, pp 265-278.

Saito, Y. (1979): Comparative studies on life histories of three species of spider mites (Acarina: Tetranychidae). Appl Entomol Zool 14:83- 94.

Wate, G.K. (2002): Pests and pollinators of mango. In: Pen`a JE, Sharp JL, Wysoki M (eds) Tropical fruit pestsand pollinators, biology, economic importance, natural enemies and control. CABI, Wallingford, pp 103 129.

Waterhouse, D.F. (1993): The major arthropod pests and weeds of agriculture in Southeast Asia. CABI, Wallingford.

Wrensch, D.L. (1985): Reproductive parameters. In: Helle W, Sabelis MW (eds) World crop pest 1A: spider mites: their biology, natural enemies and control. Elsevier, Amsterdam, pp 165-170.

Zaher, M.A. and Shehata, K.K. (1971): Biology of the red spider mite, Oligonychus mangiferus (R. \& S.) (Acarina: Tetranychidae). Bulletin de la Socie'te' Entomologique D’Egypte 55:393-401.

\section{Oligonychus mangiferus Rahman and Sapra تاثير درجات الحرارة على بيولوجي الأكساروس (Acari: Tetranychidae)

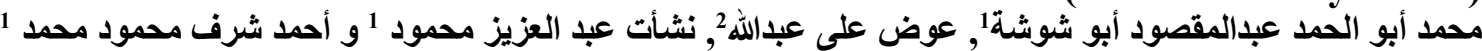

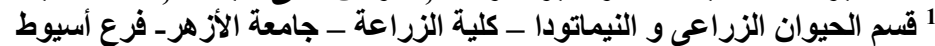

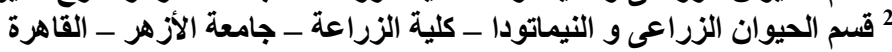

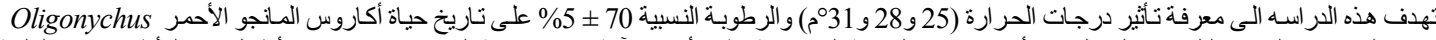


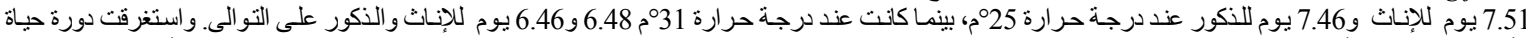

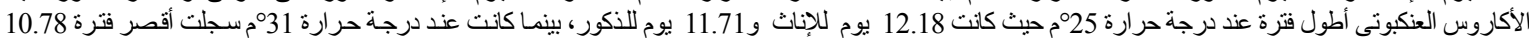

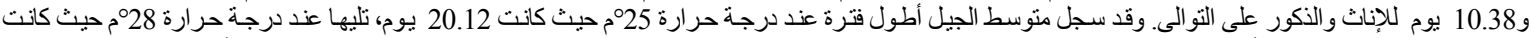

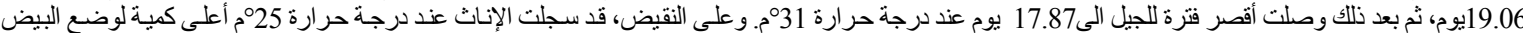

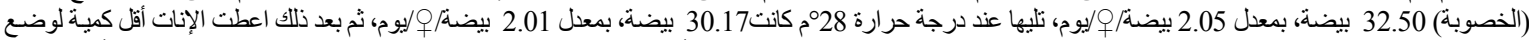

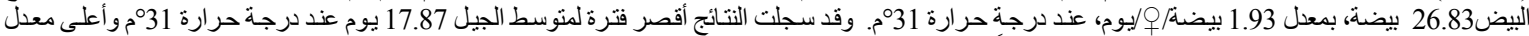

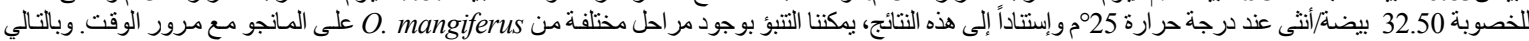
فإن هذه المعلومات تمكنتا من الدقة فى تحديد الوقت المناسب للسيطرة على هذه الآفة. 